\title{
Bone Cancer cM1a TNM Finding v8
}

National Cancer Institute

\section{Source}

National Cancer Institute. Bone Cancer CM1a TNM Finding v8. NCI Thesaurus. Code C136566.

Bone cancer with metastasis in the lung. (from AJCC 8th Ed.) 